\title{
Impact of Mild Oven Cooking Treatments on Carotenoids and Tocopherols of Cheddar and Depurple Cauliflower (Brassica oleracea L. var. botrytis)
}

\author{
Ancuta Nartea ${ }^{1}$, Benedetta Fanesi ${ }^{1}\left[\right.$, Pasquale Massimiliano Falcone ${ }^{1}$, Deborah Pacetti ${ }^{1, *} \mathbb{0}$, \\ Natale Giuseppe Frega ${ }^{1}$ and Paolo Lucci ${ }^{2}$ \\ 1 Department of Agricultural, Food and Environmental Sciences, Polytechnic University of Marche, \\ Via Brecce Bianche, 60131 Ancona, Italy; a.nartea@pm.univpm.it (A.N.); benedetta.fanesi@hotmail.it (B.F.); \\ p.m.falcone@staff.univpm.it (P.M.F.); n.g.frega@univpm.it (N.G.F.) \\ 2 Department of Agri-Food, Animal and Environmental Sciences, University of Udine, Via Sondrio 2/a, \\ 33100 Udine, Italy; paolo.lucci@uniud.it \\ * Correspondence: d.pacetti@univpm.it; Tel.: +39-071-2204307
}

check for updates

Citation: Nartea, A.; Fanesi, B. Falcone, P.M.; Pacetti, D.; Frega, N.G.; Lucci, P. Impact of Mild Oven Cooking Treatments on Carotenoids and Tocopherols of Cheddar and Depurple Cauliflower (Brassica oleracea L. var. botrytis). Antioxidants 2021, 10, 196. https://doi.org/10.3390/ antiox10020196

\section{Academic Editor:}

David Arraez-Roman

Received: 12 January 2021

Accepted: 26 January 2021

Published: 29 January 202

Publisher's Note: MDPI stays neutra with regard to jurisdictional claims in published maps and institutional affiliations.

Copyright: (c) 2021 by the authors. Licensee MDPI, Basel, Switzerland. This article is an open access article distributed under the terms and conditions of the Creative Commons Attribution (CC BY) license (https:// creativecommons.org/licenses/by/ $4.0 /)$

\begin{abstract}
The effect of steam and sous-vide oven procedures on liposoluble antioxidants of colored cauliflower (orange and purple) was assessed for the first time and compared with domestic practice (boiling). In raw samples, the total carotenoid content was 10-fold higher in Cheddar than in Depurple $(20.9 \pm 2.1$ vs. $2.3 \pm 0.5 \mathrm{mg} / \mathrm{kg}$ dry weight), whereas the level of tocopherols was similar $(28.5 \pm 4.4$ vs. $33 \pm 5.2 \mathrm{mg} / \mathrm{kg}$ dry weight). The Cheddar liposoluble antioxidant matter contained violaxanthin, neoxanthin, $\alpha$-carotene and $\delta$-tocopherol, not detected in Depurple. All tests increased the bioactive compounds extractability with steam oven and sous-vide displaying similar effects, lower than boiling. In boiled Cheddar cauliflower, the total carotenoids and tocopherols contents increased with cooking time until they were 13-fold and 6-fold more than in raw cauliflower, respectively. Conversely, in the Depurple variety, contents increased by half with respect to the orange variety. However, from a nutritional point of view, no differences were revealed among the three different cooking treatments in terms of vitamin A and E levels expressed in $\mu \mathrm{g} / 100 \mathrm{~g}$ of fresh vegetable because of the higher water content of boiled samples that must be considered when evaluating the effect of thermal treatment on cauliflower nutritional traits.
\end{abstract}

Keywords: boiling; carotenoids; cruciferous; steam oven; sous-vide; vitamin A; vitamin E

\section{Introduction}

Because of the growing scientific recognition that food, or food components, significantly influence human health, people have been looking for foods rich in bioactive compounds with functional effects on the prevention of nutrition-related diseases and that cause physical and mental well-being improvements.

A copious number of studies have suggested that consumption of Brassica oleracea vegetables, such as broccoli and cauliflower, can be associated with a decreased risk of common cancers, especially related to sulfur compounds [1,2]. Carotenoids are involved in the prevention and treatment of cardiovascular diseases [3]. The functional effects exerted by these vegetables are the result of synergistic action of a wide spectrum of phytochemicals, such vitamin C, lipid-soluble antioxidants (carotenoids, tocopherols), hydrophilic antioxidants (phenolic compounds) and glucosinolates [4]. The phytochemicals levels in cruciferous vegetables depend on different factors, mainly related to a plant's genetic background, postharvest handling practices and technological treatments carried out after vegetable harvest. In particular, cruciferous vegetables require a cooking process before consumption that may have a positive or negative impact on their bioactive properties.

Heat treatment can induce two opposite effects on bioactive compounds concentration: a reduction of phytochemicals level as an effect of thermal degradation and/or an increase 
of extractability of compounds as an effect of matrix softening. The extent of the two opposite effects are simultaneously related to the structure of vegetable matrix, operative conditions and chemical nature of the specific compound [5]. For example, dos Reis et al. [6] emphasized the key role of the vegetable structure, recognizing that boiling $\left(100{ }^{\circ} \mathrm{C}, 5 \mathrm{~min}\right)$ significantly increased the extractability of quercetin and kaempferol in broccoli (Brassica oleracea var. Avenger), whereas this strongly reduced them in cauliflower (Brassica oleracea var. Alphina F1). In both cases, boiled vegetables presented a lower total phenolic content and higher total carotenoid content than raw vegetable. In a similar way, a sous-vide cooking process accomplished in a water bath $\left(90^{\circ} \mathrm{C}, 20 \mathrm{~min}\right)$ increased the carotenoid availability in cauliflower and broccoli, whereas it significantly reduced the total polyphenol levels exclusively in cauliflowers. Microwave treatments led to a retention of glucosinolates in broccoli, whereas they caused a significant loss of glucosinolates in cauliflower [7].

In view of this, to achieve the beneficial effects of vegetable consumption, each vegetable should be cooked with the most suitable method able to best preserve and improve its nutritional and phytochemical value. Moreover, it is important to optimize processing parameters (i.e., temperature, time, heat transfer mode) to promote the bioactivity of the consumed vegetable and to counteract, as much as possible, undesired effects.

Emerging oven cooking processes based on mild thermal treatment of foods with minimal or rapid heating using steam as heat transfer medium, such as steam oven and sous-vide, are being investigated. Brassicaceae species are considered promising functional food ingredients, but the processing for novel food products is crucial to preserve their functionalities [8]. In this optic, mild thermal treatments could be a solution to optimize the manufacturing of foods. Their impact was recently assessed on the level of some selected antioxidants and oxidative status of salmon [9]. The results proved that steam oven treatment $\left(65^{\circ} \mathrm{C}, 20 \mathrm{~min}\right)$ was more efficient in enhancing the availability of the most important antioxidant compounds in salmon, such as the astaxanthin, than traditional convection oven process $\left(180^{\circ} \mathrm{C}, 20 \mathrm{~min}\right)$. Pellegrini et al. [7] noticed that the steam oven method $\left(100^{\circ} \mathrm{C}, 13 \mathrm{~min}\right)$ had a favorable effect on both fresh broccoli and white cauliflower, determining an increase of their glucosinolates total contents. Conversely, boiling treatment led to a retention of glucosinolates in broccoli, whereas they determined an important loss of glucosinolates in cauliflower. Florkiewicz et al. [10] emphasized that the use of the sous-vide method $\left(90^{\circ} \mathrm{C}, 45 \mathrm{~min}\right)$ was particularly disadvantageous and reduced the total content of glucosinolates in Romanesco-type cauliflower, whereas it enhanced the glucosinolates levels in broccoli.

Starting from this premise, in the present study, the impact of mild (steam- and sousvide) oven cooking treatments on carotenoid and tocopherol profiles of colored cauliflowers (Brassica oleracea L. var. botrytis) was evaluated and compared with that of traditional domestic practices, such as boiling. In addition, the effect of cooking time on carotenoids and tocopherols concentrations was assessed in each tested cooking procedure. The evolution of these compounds was monitored in samples treated with the same temperature for different cooking times.

The present study represents a first attempt to evaluate the impact of innovative mild oven treatments on lipid soluble antioxidant compounds of emerging colored cauliflowers, such Cheddar (orange) and Depurple (purple). In fact, most previous research has focused exclusively on the effects of steam oven and sous-vide on polyphenols and glucosinolates of white and green cauliflowers. Moreover, in the present study, for a first time, was outlined the carotenoid and tocopherol profile of purple cauliflowers cv Depurple. Although these compounds were recently investigated in purple cauliflower cv Graffiti [11-13], no data was found concerning the Depurple variety.

Overall, the study contributes to evaluate if mild oven technologies could represent a valuable alternative to traditional techniques for cauliflower processing. The outcomes of this study could help the food industry, as well as the consumers, in selecting the most suitable cooking process and time able to best preserve and improve the nutritional 
properties and liposoluble antioxidants availability in emerging colored cauliflowers, such as Cheddar (orange) and Depurple (purple).

\section{Materials and Methods}

\subsection{Chemicals and Reagents}

Carotenoids standards (>95\% purity; neoxanthin, violaxanthin, lutein, $\alpha$-carotene, $\beta$ carotene), tocopherols standards ( $>95 \%$ purity, $\alpha$-tocopherol, $\gamma$-tocopherol and $\delta$-tocopherol), solvents HPLC grade ( $>95 \%$ purity, acetone, acetonitrile, dichloromethane, ethanol, methanol, $n$-hexane, isopropanol, acetic acid and water), ammonium acetate (HPLC grade, $>99 \%$ ) and ascorbic acid (>99.5\%) were purchased by Merck (Darmstadt, Germany). Potassium hydroxide $(85 \%)$ and anhydrous sodium sulphate were purchased by ITW Company (Darmstadt, Germany). MilliQ water was purified with Millipure System (Millford, SC, USA).

\subsection{Cauliflower Samples}

In total, $6 \mathrm{~kg}$ of cauliflowers, Cheddar and Depurple varieties, were provided by a local company (Agrinovana S.r.l Petritoli, Fermo, Italy). The cauliflower rosettes were removed of damaged tissue, leaves and stems, water washed and cut into small pieces of $9 \pm 3 \mathrm{~g}$ of 3-4 cm in diameter and $4 \mathrm{~cm}$ in length, homogenized and divided into 27 portions of $180-200 \mathrm{~g}$.

\subsection{Cooking Treatments}

The operative cooking conditions for each thermal treatment (boiling, steam-oven and sous-vide) applied to cook the different cauliflower varieties are summarized in Table 1. For boiling (B), one portion of cauliflowers (180-200 g) was dipped in unsalted water $(1.5 \mathrm{~L})$ at boiling point in a pot of $18 \mathrm{~cm}$ diameter and cooked for 10 and $25 \mathrm{~min}$. For the steam oven (SO) treatment, we used an oven (Bosch, HSG636ES1) purchased in a local distributor (MediaWorld Italy) with steam injection in the chamber $(\mathrm{RH} \%=100)$, and the vegetable were cooked at $95^{\circ} \mathrm{C}$ at different times (10, 25, $\left.40 \mathrm{~min}\right)$. For sous-vide (SV) cooking, cauliflowers were vacuum-packed in a polypropylene heat-resistant (up to $120^{\circ} \mathrm{C}$ ) bag and submitted to steam oven cooking as reported above. In SO and SV, the oven was not preheated to respect the oven producer program. Each cooking trial was conducted in triplicate. Once cooked, cauliflowers were cooled down to room temperature, knife-cut in small pieces, freeze-dried (Virtis Wizard 2.0 instrument, SP Industries, New York, NY, USA), milled and stored in vacuum pouches at $-18^{\circ} \mathrm{C}$. Time and temperature conditions of the three cooking methods were chosen following real household conditions when adopting traditional water boiling or modern commercial ovens, programmed for mild treatments (steam oven and sous-vide).

Table 1. Cooking treatment and parameters (time, temperature) applied to Cheddar (C) and Depurple (D) cauliflower varieties.

\begin{tabular}{|c|c|c|c|c|}
\hline Cooking Treatment & Equipment & Temperature $\left({ }^{\circ} \mathrm{C}\right)$ & Time (min) & Sample ID ${ }^{1}$ \\
\hline Boiling (B) & Inox pan & 100 & $\begin{array}{l}10 \\
25\end{array}$ & $\begin{array}{l}\text { CB10, DB10 } \\
\text { CB25, DB25 }\end{array}$ \\
\hline Steam oven $(\mathrm{SO})$ & Oven, steam injection $(\mathrm{RH} \%=100 \%)$ & 95 & $\begin{array}{l}10 \\
25 \\
40\end{array}$ & $\begin{array}{l}\text { CSO10, DSO10 } \\
\text { CSO25, DSO25 } \\
\text { CSO40, DSO40 }\end{array}$ \\
\hline Sous-vide (SV) & $\begin{array}{c}\text { Oven, steam injection } \\
(\mathrm{RH} \%=100 \%) \text {, vacuum sealer } \\
\text { machine, food grade plastic poches }\end{array}$ & 95 & $\begin{array}{l}10 \\
25 \\
40\end{array}$ & $\begin{array}{l}\text { CSV10, DSV10 } \\
\text { CSV25, DSV25 } \\
\text { CSV40, DSV25 }\end{array}$ \\
\hline
\end{tabular}

\footnotetext{
${ }^{1}$ Sample ID abbreviation: $\mathrm{XYn}, \mathrm{X}=$ cauliflower variety, $\mathrm{Y}=$ cooking treatment, $n=$ cooking time.
} 


\subsection{Carotenoids Determination}

Carotenoids were extracted in accordance with Biswas et al. [14]. Briefly, freeze dried vegetable $(100 \mathrm{mg})$ was added to acetone $\left(5 \mathrm{~mL}, 4^{\circ} \mathrm{C}\right)$, kept at $4 \pm 1{ }^{\circ} \mathrm{C}(15 \mathrm{~min})$, vortexed (5 min) and centrifuged $\left(1370 \mathrm{rpm}, 10 \mathrm{~min}, 4^{\circ} \mathrm{C}\right)$, repeating the acetone extraction a second time. The supernatant was filtered $(0.45 \mu \mathrm{m}$, Sartorius Regenerated Cellulose Membrane), dried, resuspended in $0.5 \mathrm{~mL}$ acetone for Cheddar samples and $0.25 \mathrm{~mL}$ for Depurple ones and injected in an Acquity Ultra Pressure Liquid Chromatographic H-class system (Waters Corporation, Milford, CT, USA), equipped with Photodiode Array Detector (PDA). A faster version (20 min rather than $46 \mathrm{~min}$ ) of the method developed by Chauveau-Duriot et al. [15] was applied using an Acquity column UPLC BEH C18 $(2.1 \mathrm{~mm} \times 100 \mathrm{~mm}, 1.7 \mu \mathrm{m})$. The mobile phase was composed by phase A consisting of acetonitrile (75\%), dichloromethane $(10 \%)$ and methanol $(15 \%)$, and phase B consisting of acetate ammonium in water $(0.05 \mathrm{M})$. Gradient started at 75:25 (A:B) for $10 \mathrm{~min}, 98: 2$ (A:B) from 10 to $11 \mathrm{~min}$, 98:2 (A:B) for $20 \mathrm{~min}$. Flow rate was $0.4 \mathrm{~mL} / \mathrm{min}$, column oven was set at $35^{\circ} \mathrm{C}$ and the sample loading was carried out at $20^{\circ} \mathrm{C}$. PDA analysis was performed at a wavelength of $450 \mathrm{~nm}$ using spectrum scanning in the $210-500 \mathrm{~nm}$ range. Carotenoids were identified by comparison of retention time and absorbance spectrum with pure standards. Their quantification was performed by external calibration. Good correlation coefficients $\left(R^{2}\right)$ of 0.999 were obtained in all cases. The instrumental limit of detection (LOD) and quantification (LOQ), calculated with a signal-to-noise ratio of 3:1 and 10:1, respectively, were as follows: neoxanthin, 6 and 21; vioxanthin, 9 and 31, lutein 5 and 16, $\alpha$-carotene, 5 and 18, and $\beta$-carotene, 5 and $18 \mathrm{ng} / \mathrm{mL}$.

Retinol activity equivalent (RAE) was calculated considering $1 \mu \mathrm{g}$ retinol for each $6 \mu \mathrm{g}$ of $\beta$-carotene or $12 \mu \mathrm{g}$ of other provitamin A carotenoids [16].

\subsection{Tocopherols Determination}

Preliminary tests were conducted to optimize tocopherol determination, by direct acetone extraction and saponification as reported by Knecht et al. [17]. A modified saponification procedure was optimized for cauliflower: $0.4 \mathrm{~g}$ of powder freeze dried vegetable was added of ascorbic acid $(1 \mathrm{~g})$, sodium sulphate $(0.1 \mathrm{~g})$, ethanol $(20 \mathrm{~mL})$, potassium hydroxide solution $80 \%(4 \mathrm{~mL})$ and saponified in a water bath $\left(85^{\circ} \mathrm{C}, 30 \mathrm{~min}\right)$, shaken from time to time. The sample was cooled to room temperature, water was added (12 mL), extracted three times with $n$-hexane $(20,10$ and $20 \mathrm{~mL}$ ) and centrifuged for better separation ( $2 \mathrm{~min}, 3600 \mathrm{rpm})$. The organic phases were pooled, washed four times with water $(10 \mathrm{~mL})$, dried with rotavapor at $35^{\circ} \mathrm{C}$ and dissolved in $n$-hexane $(1 \mathrm{~mL})$ and injected in the UPLC system (UPLC Acquity H-Class, Waters Corporation, Milford, CT, USA) equipped with a Fluorimetric Detector (FLD) and an Ascentis Express HILIC column $(15 \mathrm{~cm} \times 2.1 \mathrm{~mm}$, $2.7 \mu \mathrm{m})$. An isocratic elution ( $8 \mathrm{~min}$ ) of $n$-hexane $(95.5 \%)$, isopropanol $(0.4 \%)$ and acetic acid $(0.1 \%)$ at $0.3 \mathrm{~mL} / \mathrm{min}$ was performed at $30^{\circ} \mathrm{C}$. FLD was set with an excitation and emission wavelength of 290 and $330 \mathrm{~nm}$, respectively. Tocopherols were identified by comparison of the retention time with pure standards and quantified with external calibration. Standard stock solutions of each tocopherol $(\alpha-\mathrm{T}, \gamma-\mathrm{T}, \delta-\mathrm{T})$ in isopropanol were prepared in the range of $3.5-100 \mu \mathrm{g} / \mathrm{mL}$, and good correlation coefficients were obtained for the calibration curves $\left(\mathrm{R}^{2}=0.9836-0.9965\right)$ [6]. Limit of detection (LOD) and limit of quantification (LOQ) were as follows: $\alpha$-tocopherol, 4 and 14, $\gamma$-tocopherol, 3 and 11 and $\delta$-tocopherol, 2 and $7 \mathrm{ng} / \mathrm{mL}$.

Vitamin E was calculated considering only $\alpha$-tocopherol as proposed by the EFSA NDA Panel [18].

\subsection{Statistical Analysis}

Data are reported as mean values \pm standard deviation (SD) of three replicates. Data were analyzed by a one-way ANOVA and Tukey's mean comparison test at a significance level of $p<0.05$, as well as principal component analysis (PCA) using R software version 3.5.0. 


\section{Results and Discussion}

\subsection{Impact of Thermal Processing on Carotenoid and Tocopherol Levels}

Colored cauliflowers (Brassica oleracea L. var. botrytis), such as Cheddar (orange) and Depurple (purple), are born out of a spontaneous mutation. The presence of the Or gene perturbs the normal carotenogenesis and the main carotenoid accumulated is $\beta$-carotene, which can reach great levels, namely, 25 -fold higher $\beta$-carotene levels as compared to white cauliflower, causing it to turn orange [19]. The Purple (Pr) gene in cauliflower mutates the pattern of anthocyanin accumulation, coloring the curds and a few other tissues [20]. These colored cauliflowers have recently attracted great attention by consumers due to their high biodiversity, visible not only because of their outer appearance but also their phytochemical profiles $[21,22]$. Our outcomes highlighted such peculiarities. In fact, considering the raw samples, Cheddar and Depurple have showed marked differences in terms of fat-soluble antioxidants (Table 2). The total carotenoid content was 10-fold higher in Cheddar than in Depurple. The most abundant carotenoid in Cheddar was $\beta$-carotene, followed by lutein, whereas in Depurple, lutein was the most plentiful followed by $\beta$-carotene. Violaxanthin, neoxanthin and $\alpha$-carotene were solely detected in Cheddar. Our findings agree with those provided by previous research focusing on Cheddar and a different purple cauliflower (Graffiti cv) [12,19]. However, our results differed in part from those of [11], as lutein and $\alpha$-carotene in raw Cheddar samples were not quantified, and in purple (Graffiti variety) only neoxanthin $(36.5 \mathrm{mg} / \mathrm{kg}$ dried) was found. Additionally, zeaxanthin and cryptoxanthin have been recently found at low levels in raw Cheddar [13]. However, such differences could be attributed to the different analytical methodology used for carotenoid extraction and detection. As regards the tocopherol matter, raw Cheddar and Depurple cauliflowers mainly contained $\gamma$-tocopherol $(\gamma-\mathrm{T})$, followed by $\alpha$-tocopherol $(\alpha-\mathrm{T})$. $\delta$-tocopherol $(\delta-\mathrm{T})$ was solely revealed in Cheddar variety, for the first time in such a matrix, to the best of our knowledge. A predominance of $\gamma$-T upon $\alpha$-T was also found in Cheddar and Graffiti cauliflowers [13].

Aiming to give an overview of the impact of traditional and innovative oven cooking procedures on the carotenoids and tocopherols levels, three types of cooking treatments (boiling, steam oven and sous-vide) at different cooking times were applied using two cauliflower varieties. As a result, steam oven (SO) and sous-vide (SV) were performed at $95^{\circ} \mathrm{C}$ for 10,25 and $40 \mathrm{~min}$. Boiling was performed at $100{ }^{\circ} \mathrm{C}$ for 10 and $25 \mathrm{~min}$. The carotenoids and tocopherols contents $(\mathrm{mg} / \mathrm{kg}$ dry weight) recorded in raw and processed cauliflowers are reported in Table 2.

Following the principal component analysis (PCA) performed on a dataset obtained applying eight variables (neoxanthin, violaxanthin, lutein, $\alpha$ - and $\beta$-carotene and $\alpha-, \gamma-$ and $\delta$-tocopherol), the loading plot (Figure $1 \mathrm{a}$ ), along the two first principal components (PC1 and PC2), explained $75.44 \%$ and $14.77 \%$ of the total variance of the cauliflower model, respectively. The score plot (Figure 1b) clearly highlighted that the impact of the tested cooking procedures on liposoluble antioxidants contents was linked to different factors, such as cauliflower genotype, type and time of cooking process. In fact, Cheddar and Depurple cauliflower samples were split into two distinct clusters. Within each cluster, the samples were grouped according to the cooking test $(\mathrm{B}, \mathrm{SO}, \mathrm{SV})$ and the time of process $(10,25,40 \mathrm{~min})$. In both cases, raw, steam oven (SO) and sous-vide (SV) samples were grouped together, while boiled samples were clearly distanced. Furthermore, the sample boiled for $25 \mathrm{~min}$ can be distinguished from the sample boiled for $10 \mathrm{~min}$. 
Table 2. Carotenoids and tocopherols content in raw, boiled (B), steam oven (SO) and sous-vide (SV) cauliflowers.

\begin{tabular}{|c|c|c|c|c|c|c|c|c|c|c|}
\hline & \multicolumn{7}{|c|}{ Carotenoids (mg/kg Dry Weight) } & \multicolumn{3}{|c|}{ Tocopherols (mg/kg Dry Weight) } \\
\hline & Neoxanthin & Violaxanthin & Lutein & $\beta$-Carotene & $\alpha$-Carotene & $\sum$ Carotenoids & $\alpha-\mathrm{T}$ & $\gamma-\mathrm{T}$ & $\delta-\mathrm{T}$ & $\sum$ Tocopherol \\
\hline \multicolumn{11}{|l|}{ Cheddar } \\
\hline CRaw & $<\mathrm{LOD}$ & $0.2 \pm 0.1^{\mathrm{a}}$ & $2.7 \pm 0.3^{\mathrm{a}}$ & $17.8 \pm 2.4^{\mathrm{a}}$ & $0.2 \pm 0.1^{\mathrm{a}}$ & $20.9 \pm 2.1^{\mathrm{a}}$ & $8.4 \pm 0.6^{\mathrm{a}}$ & $17.9 \pm 3.8^{\mathrm{a}}$ & $2.2 \pm 0.1^{\mathrm{a}}$ & $28.5 \pm 4.4^{\mathrm{a}}$ \\
\hline CB25 & $0.3 \pm 0.1$ & $4.5 \pm 0.6^{\mathrm{d}}$ & $36.7 \pm 0.2^{\mathrm{e}}$ & $268.5 \pm 13.4^{\mathrm{f}}$ & $4.0 \pm 0.3^{\mathrm{e}}$ & $314.6 \pm 13.9^{f}$ & $26.6 \pm 2.8^{\mathrm{d}}$ & $144.1 \pm 9.4^{\mathrm{e}}$ & $6.1 \pm 0.9^{d}$ & $176.7 \pm 13.1^{d}$ \\
\hline $\mathrm{CSO} 10$ & $0.1 \pm 0.0$ & $2.5 \pm 0.3^{c}$ & $12.4 \pm 1.1^{\mathrm{b}, \mathrm{c}}$ & $99.7 \pm 4.8^{c}$ & $1.3 \pm 0.3^{b, c}$ & $116.1 \pm 5.5^{b, c}$ & $14.5 \pm 1.6^{b}$ & $70.3 \pm 7.4^{b, c}$ & $3.4 \pm 0.5^{b}$ & $88.1 \pm 9.4^{\mathrm{b}}$ \\
\hline $\mathrm{CSO} 25$ & $<\mathrm{LOQ}$ & $1.0 \pm 0.1^{\mathrm{b}}$ & $15.5 \pm 0.4^{\mathrm{c}}$ & $135.6 \pm 7.2^{\mathrm{d}}$ & $1.4 \pm 0.1^{\mathrm{b}, \mathrm{c}}$ & $153.4 \pm 7.1^{\mathrm{d}}$ & $15.7 \pm 2.2^{b, c}$ & $83.7 \pm 8.9^{c}$ & $3.7 \pm 0.4^{b}$ & $103.0 \pm 10.9^{b, c}$ \\
\hline $\mathrm{CSO} 40$ & $<\mathrm{LOQ}$ & $0.2 \pm 0.1^{\mathrm{a}}$ & $14.5 \pm 1.9^{c}$ & $142.7 \pm 12.0^{\mathrm{d}}$ & $1.9 \pm 0.4^{c, d}$ & $159.3 \pm 12.0^{\mathrm{d}}$ & $14.4 \pm 0.7^{\mathrm{b}}$ & $68.9 \pm 8.6^{\mathrm{b}, \mathrm{c}}$ & $3.5 \pm 0.3^{\mathrm{b}}$ & $86.8 \pm 9.4^{b}$ \\
\hline CSV10 & $<\mathrm{LOD}$ & $0.3 \pm 0.0^{\mathrm{a}}$ & $9.9 \pm 1.3^{b}$ & $67.6 \pm 1.2^{\mathrm{b}}$ & $0.9 \pm 0.0^{\mathrm{b}}$ & $78.6 \pm 0.2^{b}$ & $9.4 \pm 1.2^{\mathrm{a}}$ & $49.7 \pm 7.2^{b}$ & $3.4 \pm 0.4^{\mathrm{b}}$ & $62.5 \pm 6.3^{\mathrm{b}}$ \\
\hline CSV25 & $<\mathrm{LOD}$ & $<\mathrm{LOD}$ & $14.9 \pm 2.2^{c}$ & $123.1 \pm 12.9^{\mathrm{cd}}$ & $1.3 \pm 0.3^{b, c}$ & $139.3 \pm 15.4^{c, d}$ & $14.7 \pm 1.4^{\mathrm{b}}$ & $65.2 \pm 8.4^{b}$ & $3.3 \pm 0.5^{b}$ & $83.3 \pm 10.2^{b}$ \\
\hline CSV40 & $<\mathrm{LOD}$ & $0.1 \pm 0.0^{\mathrm{a}}$ & $15.9 \pm 0.5^{c}$ & $142.2 \pm 2.7^{\mathrm{d}}$ & $1.5 \pm 0.2^{b, c}$ & $159.7 \pm 3.1^{\mathrm{d}}$ & $14.4 \pm 0.3^{b}$ & $63.1 \pm 4.4^{\mathrm{b}}$ & $3.5 \pm 0.6^{b, c}$ & $81.0 \pm 4.7^{\mathrm{b}}$ \\
\hline \multicolumn{11}{|l|}{ Depurple } \\
\hline DRaw & $<\mathrm{LOD}$ & $<\mathrm{LOD}$ & $1.5 \pm 0.3^{\mathrm{a}}$ & $0.8 \pm 0.2^{\mathrm{a}}$ & $<\mathrm{LOD}$ & $2.3 \pm 0.5^{\mathrm{a}}$ & $11.1 \pm 0.9^{\mathrm{a}}$ & $22.7 \pm 4.3^{\mathrm{a}}$ & $<\mathrm{LOD}$ & $33.8 \pm 5.2^{\mathrm{a}}$ \\
\hline DB10 & $<\mathrm{LOD}$ & $<\mathrm{LOD}$ & $7.2 \pm 0.6^{c}$ & $3.7 \pm 0.2^{d}$ & $<\mathrm{LOD}$ & $10.9 \pm 0.7^{\mathrm{d}}$ & $20.8 \pm 1.3^{\mathrm{d}}$ & $69.6 \pm 2.5^{d}$ & $<$ LOQ & $90.4 \pm 3.8^{c}$ \\
\hline DB25 & $<\mathrm{LOD}$ & $<\mathrm{LOD}$ & $9.5 \pm 1.4^{\mathrm{d}}$ & $4.4 \pm 0.2^{\mathrm{d}}$ & $<\mathrm{LOD}$ & $13.9 \pm 1.6^{\mathrm{e}}$ & $29.7 \pm 2.8^{\mathrm{e}}$ & $104.5 \pm 7.5^{\mathrm{e}}$ & $<\mathrm{LOQ}$ & $134.1 \pm 10.2^{d}$ \\
\hline DSO10 & $<\mathrm{LOD}$ & $<\mathrm{LOD}$ & $3.2 \pm 0.7^{\mathrm{b}}$ & $2.2 \pm 0.2^{\mathrm{c}}$ & $<\mathrm{LOD}$ & $5.4 \pm 0.8^{b, c}$ & $17.6 \pm 2.1^{\mathrm{c}, \mathrm{d}}$ & $50.2 \pm 4.9^{c}$ & $<\mathrm{LOQ}$ & $67.8 \pm 6.9^{b}$ \\
\hline $\mathrm{DSO} 25$ & $<\mathrm{LOD}$ & $<\mathrm{LOD}$ & $4.1 \pm 0.1^{b}$ & $2.4 \pm 0.3^{c}$ & $<\mathrm{LOD}$ & $6.5 \pm 0.3^{c}$ & $15.0 \pm 1.0^{\mathrm{b}, \mathrm{c}}$ & $33.3 \pm 6.4^{\mathrm{a}, \mathrm{b}}$ & $<\mathrm{LOQ}$ & $51.4 \pm 7.3^{b}$ \\
\hline $\mathrm{DSO} 40$ & $<\mathrm{LOD}$ & $<\mathrm{LOD}$ & $3.2 \pm 0.5^{b}$ & $2.0 \pm 0.3^{c}$ & $<\mathrm{LOD}$ & $5.3 \pm 0.8^{b, c}$ & $16.4 \pm 1.5^{\mathrm{b}, \mathrm{d}}$ & $43.9 \pm 2.1^{b, c}$ & $<\mathrm{LOQ}$ & $60.3 \pm 3.6^{b}$ \\
\hline DSV10 & $<\mathrm{LOD}$ & $<\mathrm{LOD}$ & $2.1 \pm 0.4^{\mathrm{a}}$ & $1.2 \pm 0.3^{\mathrm{a}, \mathrm{b}}$ & $<\mathrm{LOD}$ & $3.3 \pm 0.7^{a, b}$ & $12.8 \pm 1.4^{\mathrm{a}, \mathrm{b}}$ & $27.8 \pm 7.7^{\mathrm{a}}$ & $<\mathrm{LOQ}$ & $40.6 \pm 8.9^{a}$ \\
\hline DSV40 & $<\mathrm{LOD}$ & $<\mathrm{LOD}$ & $4.1 \pm 0.3^{b}$ & $2.2 \pm 0.2^{c}$ & $<\mathrm{LOD}$ & $6.3 \pm 0.5^{c}$ & $15.6 \pm 2.1^{\mathrm{a}, \mathrm{b}, \mathrm{c}}$ & $36.2 \pm 5.7^{b}$ & $<\mathrm{LOQ}$ & $51.8 \pm 7.8^{b}$ \\
\hline
\end{tabular}

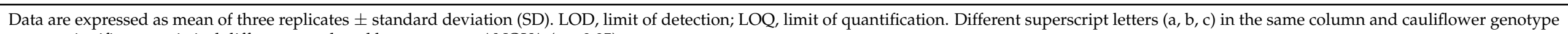
mean a significant statistical difference analyzed by a one-way ANOVA $(p<0.05)$. 
(a)

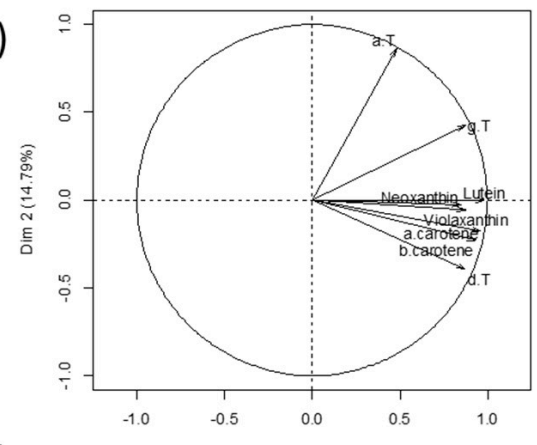

(b)

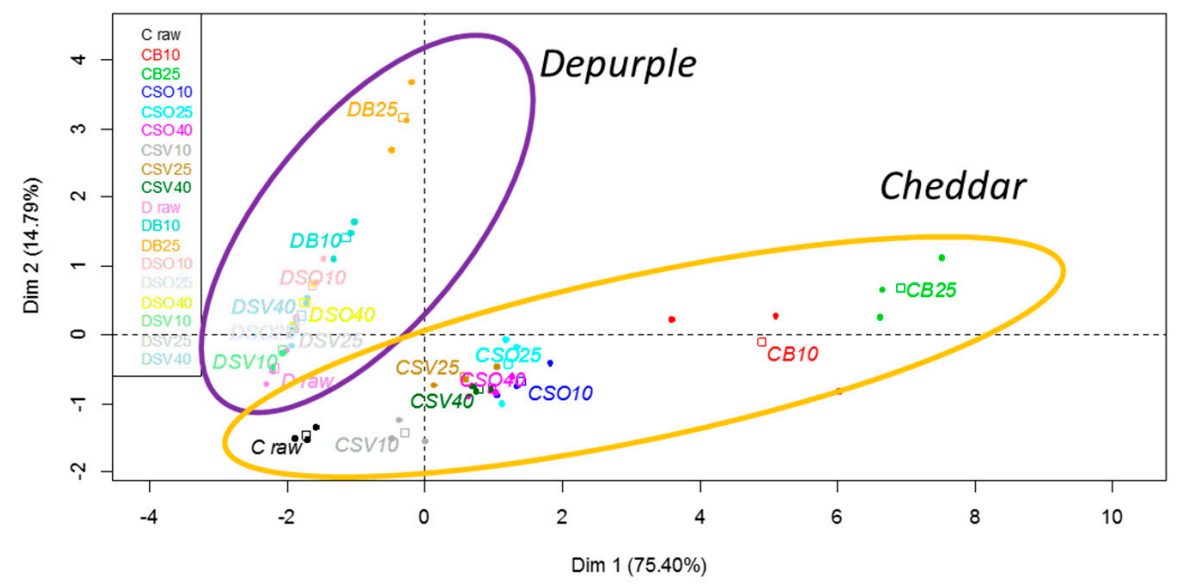

Figure 1. Loading plot of the principal component analysis performed in raw and cooked Cheddar and Depurple cauliflower by applying eight variables (a). Score plot principal component analysis performed in raw and cooked Cheddar (C) and Depurple (D) cauliflower (b).

On these bases, it can be supposed that steam oven and sous-vide treatments had a similar impact on the liposoluble antioxidant profile of cauliflowers. Such an impact can be differentiated from that of the boiling process, which also depended on the cooking time.

To corroborate this hypothesis, an ANOVA analysis was also performed. For each compound, within the same cauliflower genotype, significant differences $(p<0.05)$ were highlighted according to the different types of cooking and times. As a consequence, the impact of each investigated cooking practice on each compound for both cauliflower genotypes was investigated and separately discussed in the following subsubsection.

\subsubsection{Boiling}

Cooking by boiling significantly increases the extractability of all carotenoids and tocopherols, in both cauliflowers. However, the boiling impact on the compound level enhancement depends on the cauliflower variety (matrix effect), kind of compound and time of cooking. The impact was stronger in Cheddar rather than in Depurple. For example, in Cheddar boiled for $25 \mathrm{~min}$ (CB25), the total carotenoids and tocopherols contents increased 15-fold and 6-fold, respectively, if compared with the raw sample. Conversely, in Depurple, 25 min of boiling (DB25) enhanced the total carotenoids six-fold and the total tocopherol amounts four-fold.

Considering the behavior of each carotenoid compound, the neoxanthin and violaxanthin, which were revealed solely in Cheddar, reached significantly highest values for boiling with respect to steam oven and sous-vide treatments. Their amounts in CB25 were not statistically different from those detected in CB10. A different performance was seen for $\alpha$-carotene, the other carotenoid exclusively found in Cheddar. Its highest level was achieved after $25 \mathrm{~min}$ of boiling. Diamante et al. [13] also found a higher $\alpha$-carotene level in Cheddar and Graffiti boiled for 20 min rather than in that boiled for $10 \mathrm{~min}$. 
Lutein displayed a significant increase between 10 and $25 \mathrm{~min}$ of boiling, both for Cheddar and Depurple, whereas 25 min of boiling significantly enhanced the $\beta$-carotene amount after only $10 \mathrm{~min}$ in Cheddar. These findings were partially in contrast with those reported by Diamante et al. [13], showing that a boiling time of up 10 min provoked a decrease of lutein and a retention of $\beta$-carotene level in Cheddar cauliflower, whereas it led to an increase of both compounds in the Graffiti cauliflower.

As regards tocopherol matter, 10 and 25 min of boiling significantly increased the release of all tocopherol compounds $(\alpha-, \gamma$ - and $\delta$-) in both cauliflowers. It is interesting to notice that the ratio of $\gamma-\mathrm{T} / \alpha$-T increased from 2 (raw) to around 5 (boiled, 10 and $25 \mathrm{~min}$ ) in both varieties, suggesting $\gamma$-tocopherol is more retained after cooking, as reported by Lee et al. [23] in 5-min boiled broccoli, probably because heat softens plant tissue by cell disruption and may inactivate tocopherol oxidase enzyme.

\subsubsection{Steam Oven}

Heat transferred to cauliflower by steam (steam oven, $95^{\circ} \mathrm{C}$ ) had a positive influence on the extractability of both carotenoids and tocopherols. After 25 min of treatment, SO led to a 7.3-fold higher total content of carotenoids compared to raw Cheddar cauliflower and to a 2.8-fold increase in Depurple. Simultaneously, the total tocopherol content went up by 3.6-fold and 1.5-fold in Cheddar and Depurple, respectively.

However, the steam oven extractability of carotenoids and tocopherols decreased by two-fold if compared with that of the boiling treatment performed at the same cooking time (i.e., 10 or $25 \mathrm{~min}$ ). This difference may be the result of a stronger impact of hot water than steam on the microstructure of vegetable tissue. It is widely accepted that the heat may activate the chemical depolymerization reactions of the structural pectin. Such depolymerization reactions cause the disruption of the middle lamella, thus promoting the cell-to-cell separation and the early softening of the vegetable texture. These reactions can progress to such an extent to cause the rupture of the cell wall, promoting the increase of the extractability of the cell contents. The level of the extractability of the compounds, which are compartmentalized at different hierarchical levels in the vegetable tissues, mainly depends on the degree of the extent of pectin degradation reactions, which in turn depends on the specific cooking conditions which include temperature, time of cooking and water availability.

Considering the same cooking time (10 or $25 \mathrm{~min}$ ), we found that the samples obtained after boiling (CB10, CB25, DB10, DB25) had higher tenderness than the respective steamed samples (CSO10, CSO25, DSO10, DSO25) (data not shown). It is plausible to suppose that steam oven treatment requires more time to reach a similar tenderness to boiled tissues. Accordingly, Borowski et al. [24] studied the effects of steaming and water boiling on firmness, sensory attributes and pectin composition of broccoli. They highlighted that boiling had a more invasive impact on broccoli tissue than steaming, provoking major loss in firmness and the leaching of pectin in boiling water. In fact, boiled broccoli had a lower content of total pectin, protopectin and water-soluble pectin fractions than steamed broccoli.

Furthermore, our results highlighted that the heat transfer efficiency of boiling can be different from that of steaming. In fact, if the boiling impact on the extractability of compounds increased with the cooking time, prolonging the steaming time to over $10 \mathrm{~min}$ did not yield additional enhancement of carotenoids and tocopherols levels, except for $\beta$ carotene in Cheddar, which reached the significantly highest value after $25 \mathrm{~min}$ of processing. Peculiar behavior was recognized for violaxanthin. Its amount statistically decreased if the steaming time went up to $10 \mathrm{~min}$. As a result, the violaxanthin content in the Cheddar sample that underwent 40 min of steaming (CSO40) was not different from that in the raw sample. It can be supposed the steam oven treatment longer than $10 \mathrm{~min}$ provoked the degradation of violaxanthin.

It is plausible to speculate that the texture softening kinetics of different cooking methods involving different heat transfer means (i.e., hot water, saturated steam) are not 
comparable. Xiao et al. [25] revealed that steaming could cause the formation of a dried layer on the product surface due to the evaporation of water, resulting in a non-uniform heating effect.

Since no other data concerning the effect of steam and sous-vide treatments, accomplished in an oven, on carotenoids and tocopherol matters of cauliflowers currently exists in the literature, an extensive comparison of the presented data is difficult.

In agreement with our results, Diamante et al. [13] showed that $10 \mathrm{~min}$ of steam cooking performed with a steamer pod was not enough to maximize the extraction of $\beta$-carotene in Cheddar cauliflowers, whereas it led to a higher release of lutein, $\alpha$-carotene and all tocopherols than 20 min of steaming. Other authors reported that total carotenoids significantly increased (19\%) in oven-steamed broccoli, which is a common technique in Italian cuisine [26], while vessel and oven steam cooking of fresh and frozen broccoli (around $10 \mathrm{~min}$ ) did not affect the carotenoid content of fresh and frozen counterparts [7]. Steaming (5 $\mathrm{min}$ ) registered an increment of about seven-fold lutein in uncooked kalianhybrid-broccoli [27]. Conversely, dos Reis et al. exhibited that 20-min vessel steamed organic cauliflower showed lower values of lutein, $\beta$-carotene, total carotenoids and vitamin A than raw cauliflower, and higher values of zeaxanthin, cryptoxanthin and $\alpha$-carotene [28].

\subsubsection{Sous-Vide}

It is well known that sous-vide (or in-pack cooking) is widely applied in restaurants and in catering, because it improves the texture, color and flavor of meat and vegetable foodstuffs due to two factors: the absence of oxygen inside the pack and the mild heat treatment applied [29-32].

Our results show that the ability of the sous-vide treatment to release the liposoluble antioxidants from the vegetable tissue was markedly lower than the steam oven treatment, and as a consequence, lower than boiling. In detail, the sous-vide oven process enhanced the extraction of the overall carotenoid and tocopherol content mostly in Cheddar cauliflower, namely, six-fold and three-fold more than raw cauliflower, respectively (Table 2). A lower extractability was recorded in Depurple cauliflower as the total carotenoid content increased by up to 3-fold and 1.5-fold more, respectively.

In order to maximize the $\beta$-carotene and lutein extraction, $40 \mathrm{~min}$ of sous-vide treatment was necessary for both cauliflowers. In Cheddar samples, the highest amount of $\alpha$-carotene was extracted after 40 min of sous-vide treatment, while in Depurple, $\alpha$-carotene was below the limit of detection. Differently to steam oven, 10 min of sous-vide treatment was not sufficient to maximize the extraction of lutein, in both cauliflowers. Furthermore, no significant increasing trend was observed for $\alpha$-tocopherol as a consequence of the sous-vide treatment of Depurple cauliflower. Finally, it was sufficient $10 \mathrm{~min}$ of steam oven and sous-vide treatments to maximize the extraction of $\gamma$-and $\delta$-tocopherol in Cheddar whereas the highest amount of $\gamma$-tocopherol in Depurple was achieved applying sous-vide procedure for a longer time then steam oven.

Although the steam oven and sous-vide treatments were performed at the same operative conditions, it can be supposed that there was a different heat-transfer efficiency, resulting in different time-temperature exposure of the processed samples at a given time of cooking, as well as having a different impact on tissue microstructure. It is noticeable that cauliflower tissue is rich in proteins associated with a bilayer of lipids [33]. As a result, sous-vide cooking did not reach the same cell disruption enhancement of carotenoids and tocopherols extraction as steaming did. To corroborate this hypothesis, we have found that sous-vide samples show the highest stiffness among all the cooked samples (data not shown).

\subsection{Evaluating the Impact of Thermal Processing on Nutritional Traits of Cauliflowers: Vitamin A} and $E$ Contents

Aiming to assess the impact of the tested cooking procedures on nutritional traits of the cauliflowers, vitamin A and E were calculated along EFSA NDA Panel [16,18] for 
orange and purple cauliflowers submitted to different cooking techniques (Figure 2). As a general rule, all the tested thermal treatments enhanced the extractability of provitamin $\mathrm{A}$ and $\mathrm{E}$ in Cheddar and Depurple cauliflower, with some exception in terms of value significance. Differences among traditional (boiling) and mild oven thermal technology (steam oven and sous-vide) when expressing the results of vitamin A and $\mathrm{E}$ as $\mu \mathrm{g} / 100 \mathrm{~g}$ of fresh vegetable were not observed. This is a consequence of different water uptakes, which lead to apparent changes in $\alpha$-carotene, $\beta$-carotene (retinol equivalents) and $\alpha$ tocopherol (vitamin E equivalent) concentrations. With reference to raw samples, boiled samples displayed an increment of around $4 \%$ of water, while mild oven samples displayed around $1 \%$.

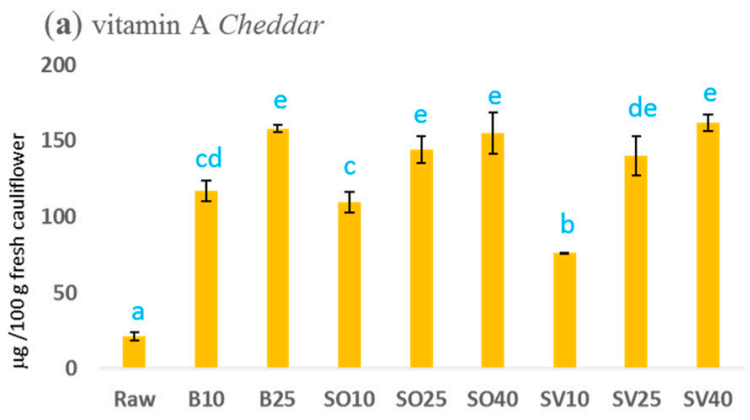

(c) vitamin E Cheddar

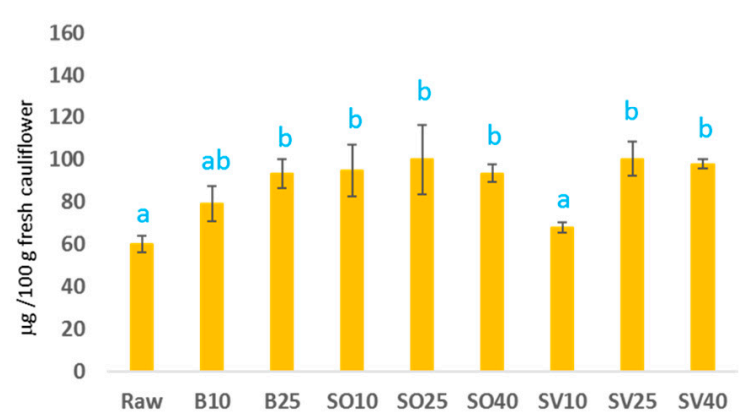

(b) vitamin A Depurple

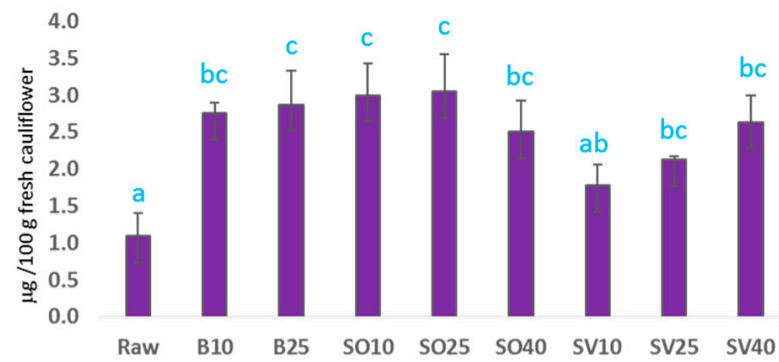

(d) vitamin E Depurple

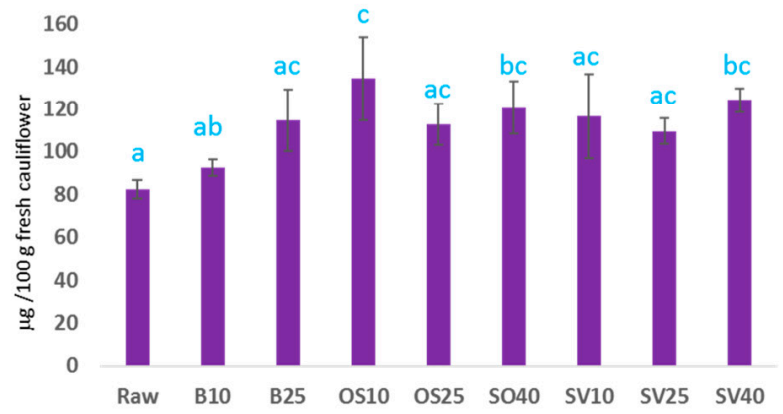

Figure 2. Vitamin A and E contents ( $\mu \mathrm{g} / 100 \mathrm{~g}$ fresh cauliflower) in raw and cooked samples. (a) Vitamin A quantified in Cheddar cauliflower. (b) Vitamin A in Depurple cauliflower. (c) Vitamin E in Cheddar variety. (d) Vitamin E in Depurple cauliflower. Data are expressed as mean of three replicates \pm standard deviation (SD). Different superscript letters (a-e) mean significant statistical difference ( $p<0.05$, one-way ANOVA).

It is of interest to focus on vitamin A content in Cheddar cauliflower, as it was a criterion for its fruitful introduction to the market. Figure 2a shows a prolonged time of boiling ( $25 \mathrm{~min}$ ), steam oven and sous-vide cooking ( 25 and $40 \mathrm{~min}$ ) provided the highest contents of vitamin A, which accounted for about $160 \mu \mathrm{g} / 100 \mathrm{~g}$ fresh cauliflower. Independently of technology, cooking enhanced the availability of vitamin A in any case, and a portion of $200 \mathrm{~g}$ of cooked cauliflower provides from 20 to $50 \%$ of the reference intakes, set at $750 \mu \mathrm{g}$ retinol equivalent (RE)/day for men and $650 \mu \mathrm{g} R$ /day for women [16]. The impact of thermal treatment in Cheddar considering vitamin A is positive. In the same way, vitamin A (Figure 2b) for the Depurple variety is enhanced after traditional and mild oven cooking, but the positive trend of time lasting is less evident because of low levels of provitamin A carotenoids, proving in the best case to be $1 \%$ (DSO25) of the adequate daily intake of vitamin A.

Considering vitamin E, Cheddar (Figure 2c) and Depurple (Figure 2d) cauliflowers showed similar levels in all samples (raw and cooked) around a media of $100 \mu \mathrm{g} / 100 \mathrm{~g}$ wet weight. The lowest values were recorded in raw samples in both varieties; thus, the cooking process did not always enhance the extractability of $\alpha$-tocopherol in a statically 
significant way. As in the case of vitamin A, boiling values were flattened to mild oven treatments because of water uptake. In terms of the satisfaction of adequate vitamin $\mathrm{E}$ intakes (13 mg/day for men, $11 \mathrm{mg}$ /day for woman) [18], a portion of $200 \mathrm{~g}$ colored cauliflower provided, in the best cooking conditions, 1.7\% (CSV25) and 2.2\% (DOS10).

\section{Conclusions}

It is well known that the heat treatment of vegetable can induce two opposite effects: a reduction of phytochemicals levels as an effect of thermal degradation and/or an increase of extractability of compounds as an effect of matrix softening.

Our results evidenced that all tested procedures led to an increase of carotenoids and tocopherols extractability in cauliflowers. However, the extent of the increase changed according to the cauliflower variety, operative conditions (time and temperature of cooking) and chemical nature of the specific compound. In any case, given the same cooking time and temperature, boiling displayed the highest ability to release all liposoluble antioxidants from the cauliflowers tissue as compared to steam oven and sous-vide methods. The latter treatments exhibited similar effects even if the impact of sous-vide was more affected by the cauliflower variety than the steam oven. In fact, the sous-vide procedure was able to enhance $\alpha$-tocopherol in Cheddar but not in Depurple cauliflower.

Although boiling presented the highest ability to release carotenoids and tocopherols, from a nutritional point of view, no differences were revealed among all cooked samples in terms of vitamin $\mathrm{A}$ and $\mathrm{E}$ contents expressed in $\mu \mathrm{g} / 100 \mathrm{~g}$ fresh vegetable. The higher water content in boiled than in steam and sous-vide samples must be considered when the effect of thermal treatment on cauliflower nutritional traits is discussed.

Author Contributions: Conceptualization, D.P. and N.G.F.; methodology, P.L.; formal analysis, A.N. and B.F.; data curation, A.N. and P.M.F.; writing-original draft preparation, A.N., D.P. and P.L.; writing-review and editing, B.F. and P.M.F.; supervision, D.P. and P.L.; project administration, D.P.; funding acquisition, D.P. and N.G.F. All authors have read and agreed to the published version of the manuscript.

Funding: This research received no external funding.

Institutional Review Board Statement: Not applicable.

Informed Consent Statement: Not applicable.

Data Availability Statement: Not applicable.

Acknowledgments: The authors would like to thank AGRINOVANA s.r.l. of Petritoli (Fermo), Italy, for providing the cauliflower samples. The authors thank the student Federica Grifa for her support in sample preparation.

Conflicts of Interest: The authors declare no conflict of interest.

\section{References}

1. Abbaoui, B.; Lucas, C.R.; Riedl, K.M.; Clinton, S.K.; Mortazavi, A. Cruciferous Vegetables, Isothiocyanates, and Bladder Cancer Prevention. Mol. Nutr. Food Res. 2018, 62. [CrossRef] [PubMed]

2. Miękus, N.; Marszałek, K.; Podlacha, M.; Iqbal, A.; Puchalski, C.; Swiergiel, A.H. Health Benefits of Plant-Derived Sulfur Compounds, Glucosinolates, and Organosulfur Compounds. Molecules 2020, 25, 3804. [CrossRef] [PubMed]

3. Kulczyński, B.; Gramza-Michałowska, A.; Kobus-Cisowska, J.; Kmiecik, D. The role of carotenoids in the prevention and treatment of cardiovascular disease-Current state of knowledge. J. Funct. Foods 2017, 38, 45-65. [CrossRef]

4. Koss-Mikołajczyk, I.; Kusznierewicz, B.; Wiczkowski, W.; Płatosz, N.; Bartoszek, A. Phytochemical composition and biological activities of differently pigmented cabbage (Brassica oleracea var. capitata) and cauliflower (Brassica oleracea var. botrytis) varieties. J. Sci. Food Agric. 2019. [CrossRef] [PubMed]

5. Palermo, M.; Pellegrini, N.; Fogliano, V. The effect of cooking on the phytochemical content of vegetables. J. Sci. Food Agric. 2014, 94, 1057-1070. [CrossRef] [PubMed]

6. Dos Reis, L.C.R.; de Oliveira, V.R.; Hagen, M.E.K.; Jablonski, A.; Flores, S.H.; de Oliveira Rios, A. Carotenoids, flavonoids, chlorophylls, phenolic compounds and antioxidant activity in fresh and cooked broccoli (Brassica oleracea var. Avenger) and cauliflower (Brassica oleracea var. Alphina F1). LWT Food Sci. Technol. 2015, 63, 177-183. [CrossRef] 
7. Pellegrini, N.; Chiavaro, E.; Gardana, C.; Mazzeo, T.; Contino, D.; Gallo, M.; Riso, P.; Fogliano, V.; Porrini, M. Effect of different cooking methods on color, phytochemical concentration, and antioxidant capacity of raw and frozen brassica vegetables. J. Agric. Food Chem. 2010, 58, 4310-4321. [CrossRef]

8. Ramirez, D.; Abellán-Victorio, A.; Beretta, V.; Camargo, A.; Moreno, D.A. Functional ingredients from brassicaceae species: Overview and perspectives. Int. J. Mol. Sci. 2020, 21, 1998. [CrossRef]

9. Orlando, P.; Giardinieri, A.; Lucci, P.; Nartea, A.; Balzano, M.; Pacetti, D.; Frega, N.G.; Silvestri, S.; Tiano, L. Impact of traditional and mild oven cooking treatments on antioxidant compounds levels and oxidative status of Atlantic salmon (Salmo salar) fillets. LWT 2020, 134. [CrossRef]

10. Florkiewicz, A.; Ciska, E.; Filipiak-Florkiewicz, A.; Topolska, K. Comparison of Sous-vide methods and traditional hydrothermal treatment on GLS content in Brassica vegetables. Eur. Food Res. Technol. 2017, 243, 1507-1517. [CrossRef]

11. Guzman, I.; Yousef, G.G.; Brown, A.F. Simultaneous extraction and quantitation of carotenoids, chlorophylls, and tocopherols in Brassica vegetables. J. Agric. Food Chem. 2012, 60, 7238-7244. [CrossRef] [PubMed]

12. Park, S.Y.; Lim, S.H.; Ha, S.H.; Yeo, Y.; Park, W.T.; Kwon, D.Y.; Park, S.U.; Kim, J.K. Metabolite profiling approach reveals the interface of primary and secondary metabolism in colored cauliflowers (Brassica oleracea L. ssp. botrytis). J. Agric. Food Chem. 2013, 61, 6999-7007. [CrossRef] [PubMed]

13. Diamante, M.S.; Vanz Borges, C.; Minatel, I.O.; Jacomino, A.P.; Basílio, L.S.P.; Monteiro, G.C.; Corrêa, C.R.; de Oliveira, R.A.; Pace Pereira Lima, G. Domestic cooking practices influence the carotenoid and tocopherol content in colored cauliflower. Food Chem. 2021, 340, 127901. [CrossRef] [PubMed]

14. Biswas, A.K.; Sahoo, J.; Chatli, M.K. A simple UV-Vis spectrophotometric method for determination of $\beta$-carotene content in raw carrot, sweet potato and supplemented chicken meat nuggets. LWT_Food Sci. Technol. 2011, 44, 1809-1813. [CrossRef]

15. Chauveau-Duriot, B.; Doreau, M.; Nozière, P.; Graulet, B. Simultaneous quantification of carotenoids, retinol, and tocopherols in forages, bovine plasma, and milk: Validation of a novel UPLC method. Anal. Bioanal. Chem. 2010, 397, 777-790. [CrossRef] [PubMed]

16. EFSA Panel on Dietetic Products, Nutrition, and Allergies (NDA). Scientific Opinion on Dietary Reference Values for vitamin A. EFSA J. 2015, 13, 4028. [CrossRef]

17. Knecht, K.; Sandfuchs, K.; Kulling, S.E.; Bunzel, D. Tocopherol and tocotrienol analysis in raw and cooked vegetables: A validated method with emphasis on sample preparation. Food Chem. 2015, 169, 20-27. [CrossRef]

18. EFSA Panel on Dietetic Products, Nutrition, and Allergies (NDA). Scientific Opinion on Dietary Reference Values for vitamin E as $\alpha$-tocopherol. EFSA J. 2015, 13, 4149. [CrossRef]

19. Li, L.; Paolillo, D.J.; Parthasarathy, M.V.; DiMuzio, E.M.; Garvin, D.F. A novel gene mutation that confers abnormal patterns of $\beta$-carotene accumulation in cauliflower (Brassica oleracea var. botrytis). Plant. J. 2001, 26, 59-67. [CrossRef]

20. Chiu, L.-W.; Zhou, X.; Burke, S.; Wu, X.; Prior, R.L.; Li, L. The Purple Cauliflower Arises from Activation of a MYB Transcription Factor. Plant. Physiol. 2010, 154, 1470-1480. [CrossRef]

21. Kapusta-Duch, J.; Szelag-Sikora, A.; Sikora, J.; Niemiec, M.; Gródek-Szostak, Z.; Kuboń, M.; Leszczyńska, T.; Borczak, B. Health-Promoting Properties of Fresh and Processed Purple Cauliflower. Sustainability 2019, 11, 4008. [CrossRef]

22. Neugart, S.; Baldermann, S.; Hanschen, F.S.; Klopsch, R.; Wiesner-Reinhold, M.; Schreiner, M. The intrinsic quality of brassicaceous vegetables: How secondary plant metabolites are affected by genetic, environmental, and agronomic factors. Sci. Hortic. 2018, 233, 460-478. [CrossRef]

23. Lee, S.; Choi, Y.; Jeong, H.S.; Lee, J.; Sung, J. Effect of different cooking methods on the content of vitamins and true retention in selected vegetables. Food Sci. Biotechnol. 2018, 27, 333-342. [CrossRef] [PubMed]

24. Borowski, J.; Narwojsz, A.; Borowska, E.J.; Majewska, K. The effect of thermal processing on sensory properties, texture attributes and pectic changes in broccoli. Czech J. Food Sci. 2015, 33, 254-260. [CrossRef]

25. Xiao, H.W.; Pan, Z.; Deng, L.Z.; El-Mashad, H.M.; Yang, X.H.; Mujumdar, A.S.; Gao, Z.J.; Zhang, Q. Recent developments and trends in thermal blanching-A comprehensive review. Inf. Process. Agric. 2017, 4, 101-127. [CrossRef]

26. Miglio, C.; Chiavaro, E.; Visconti, A.; Fogliano, V.; Pellegrini, N. Effects of different cooking methods on nutritional and physicochemical characteristics of selected vegetables. J. Agric. Food Chem. 2008, 56, 139-147. [CrossRef]

27. Martínez-Hernández, G.B.; Artés-Hernández, F.; Gómez, P.A.; Artés, F. Induced changes in bioactive compounds of kailan-hybrid broccoli after innovative processing and storage. J. Funct. Foods 2013, 5, 133-143. [CrossRef]

28. dos Reis, L.C.R.; de Oliveira, V.R.; Hagen, M.E.K.; Jablonski, A.; Flores, S.H.; de Oliveira Rios, A. Effect of cooking on the concentration of bioactive compounds in broccoli (Brassica oleracea var. Avenger) and cauliflower (Brassica oleracea var. Alphina F1) grown in an organic system. Food Chem. 2015, 172, 770-777. [CrossRef]

29. Chiavaro, E.; Mazzeo, T.; Visconti, A.; Manzi, C.; Fogliano, V.; Pellegrini, N. Nutritional quality of sous vide cooked carrots and brussels sprouts. J. Agric. Food Chem. 2012, 60, 6019-6025. [CrossRef]

30. Rinaldi, M.; Dall'Asta, C.; Meli, F.; Morini, E.; Pellegrini, N.; Gatti, M.; Chiavaro, E. Physicochemical and Microbiological Quality of Sous-Vide-Processed Carrots and Brussels Sprouts. Food Bioprocess Technol. 2013, 6, 3076-3087. [CrossRef]

31. Muñoz, S.; Achaerandio, I.; Yang, Y.; Pujolà, M. Sous Vide Processing as an Alternative to Common Cooking Treatments: Impact on the Starch Profile, Color, and Shear Force of Potato (Solanum tuberosum L.). Food Bioprocess Technol. 2017, 10, 759-769. [CrossRef] 
32. Rinaldi, M.; Dall'Asta, C.; Paciulli, M.; Cirlini, M.; Manzi, C.; Chiavaro, E. A Novel Time/Temperature Approach to Sous Vide Cooking of Beef Muscle. Food Bioprocess Technol. 2014, 7, 2969-2977. [CrossRef]

33. Garcia-Ibañez, P.; Nicolas-Espinosa, J.; Carvajal, M. Plasma Membrane Vesicles From Cauliflower Meristematic Tissue And Their Role In Water Passage. BMC Plant Biol. 2020, 21. [CrossRef] 